\title{
A Review to the Development of Foreign Capital Manufacturing Industry in China: Looking forward to Made in China, 2025
}

\author{
Jiawan Xia \\ South China University of Technology, Guangzhou, China \\ Email: 2423796308@qq.com
}

How to cite this paper: Xia, J.W. (2017) A Review to the Development of Foreign Capital Manufacturing Industry in China: Looking forward to Made in China, 2025. American Journal of Industrial and Business Management, 7, 604-613.

https://doi.org/10.4236/ajibm.2017.75045

Received: April 19, 2017

Accepted: May 19, 2017

Published: May 22, 2017

Copyright $\odot 2017$ by author and Scientific Research Publishing Inc. This work is licensed under the Creative Commons Attribution International License (CC BY 4.0) http://creativecommons.org/licenses/by/4.0/

\begin{abstract}
This paper argues China through the establishment of special economic zones at the beginning of reform and opening up, as well as the formulation of "super national treatment" and other preferential policies to attract foreign investment. To now have a large number of foreign manufacturing enterprises' withdraw behind China's contrast, is a reflection of China's economy growing stronger, and is the inevitable result compatible with the "made in China 2025". This paper hopes to help some enterprises to correctly understand the phenomenon of foreign investment. This paper reviews the different historical periods under the different performances of China's policy on foreign investment to explore "made in China 2025" by the historic significance, but also shows good hope for the development of Chinese manufacturing industry.
\end{abstract}

\section{Keywords}

Foreign Manufacturing, Divestment, Upgrading of Industrial Structure, "China 2025"

\section{Introduction}

In recent years, along with the group after group of extracting Chinese wellknown foreign companies, some people began to worry about the future of China manufacturing industry's economic development, thinking that China's economic development deteriorates. However, after the formulation and promulgation of "Made in China 2025", we can find that the wave of foreign capital withdrawal is actually a reflection of the rapid development of China's economy. Therefore, this article through the analysis under the different historical development periods corresponding to the foreign policy, extracts the real reasons behind the tide of foreign investment, which is adapted to China's economic de- 
velopment, and is not the expression of the Chinese economy to deteriorate. And the promulgation of "Made in China 2025" has strongly given the support to this view. It is hoping that through this article's brief analysis, it is to help enterprises to establish confidence in China's economic development, help to transform the direction for the future of manufacturing enterprises, so that they can follow the pace of China's economic development and adapt to the needs of the development of China's economy.

\section{A Brief Overview of "Made in China 2025"}

On May 19, 2015, the state council issued the "made in China 2025" and deployed a comprehensive strategy of implementing the manufacturing power. Made in China 2025 is the first decade of action by the Chinese government to implement the strategy of manufacturing great powers. "Made in China 2025", adhere to the "innovation drive, quality first, the green development, structural optimization, the talented person for this" the basic policy, adhere to the "market leading, government guidance, based on the current and long-term perspective, the whole advancement, key breakthrough, independent development, opening up and cooperation" of the basic principles, through the "three steps" to achieve the strategic goal of manufacturing power: the first step, in 2025 into the manufacturing powerhouse ranks; Second, by 2035, China's manufacturing sector will reach the middle of the world's manufacturing powerhouse. The third step, when the People's Republic of China was founded a hundred years ago, the comprehensive strength reached the forefront of the world's manufacturing power. "Made in China 2025" is under the new international and domestic environment, the Chinese government based on the change trend of international industry, make the comprehensive promotion of quality and level of development of Chinese manufacturing industry important strategic deployment. The fundamental goal is to change the situation of China's manufacturing industry "big but not strong", through 10 years of efforts, China into the manufacturing powerhouse, for by 2045 China will be completed with global lead and influence the manufacturing powerhouse to lay the solid foundation.

\section{Reform and Opening up to Help New China's Economic Development}

After the war, the economic construction of China was a very important mission. At the beginning of the founding of new China, compared to Europe and the United States and other capitalist countries, China's economic development was far behind, and during the Cultural Revolution, the chaotic economic system has brought a heavy blow to China's development. However, the world economy has been developing, China does not possibly have hundreds of years to catch up with the developed countries in terms of economic development, Chinese economy needs to rise rapidly, and the introduction of capital and technology from foreign-funded enterprises would be the best choice.

After the Third Plenary Session of the 11th, the opening to the outside world 
has become a basic national policy. This is one of the many efforts that Chinese government made to invest in attracting foreign investment to China at that time. In July 1979, Chinese government promulgated the first law on the use of foreign capital, "the Law of the People's Republic of China on Sino-foreign Equity Joint Ventures". The same year in August, the State Council set up a foreign investment management committee. In 1998, Shenzhen Special Economic Zone was established, during 1984 and 1985, Shanghai, Tianjin and other 14 coastal cities and the Yangtze River Delta, the Pearl River Delta and other economic open areas were opened. In1988, coastal economic open areas extended to coastal economic open areas include Liaodong Peninsula, Shandong Peninsula, and approved the establishment of the Hainan Special Economic Zone. In 1990, China decided to develop and open the Shanghai Pudong New Area, and gradually built "special economic zones-coastal open cities-economic open areasthe mainland" layers of progressive opening pattern. Among them, government formulated the "State Council on the encouragement of foreign investment provisions" in 1986, committed to improving the foreign-invested enterprises in China production and management conditions.

From the gradual opening of the special economic zones to the "super-national treatment" and other preferential policies introduced, foreign-funded enterprises were in a convenient investment environment, the use of cheap labor, land and property and other resources were in their own rapid development, but also became a model of reference for China's domestic enterprises to learn [1]. There is no doubt that the, foreign-funded enterprises with strong financial resources, high-level manufacturing technology and advanced management model for the rapid development of Chinese enterprises contributed a very solid force. Since the introduction of multinational corporations in China in 1992, the number of projects in infrastructure, infrastructure and pillar industries has increased, including the funds and technology-intensive projects, which supported the adjustment and improvement of China's industrial structure. At the same time, China's foreign exchange reserves increased. A country's foreign exchange reserve is the basis for its participation in international trade and communication, reflecting the wealth and strength of a country. The continued inflow of foreign capital and the continued increase in the number of foreign trade imports pushed China's foreign exchange reserves to increase rapidly. Moreover, large foreign exchange reserves for the reform of China's financial industry promoted China's finance and the international market, and laid a good foundation for RMB internationalization process, supporting a number of enterprise transformation, bringing new technology, equipment and advanced management experience, and creating a large number of employment opportunities [2]. The development of foreign-funded enterprises in China, on the one hand, has brought a lot to China advanced technology, but also the international level of scientific management methods and experience [3]. This sense of risk into the modern emerging business of international business, not only cast a large number of China's local high, intermediate management personnel and business 
personnel, but also brought the ideological collision to China's current management model, management methods and business philosophy. Our management has been improved, so did the means of operation, providing the opportunity to learn and exchange.

From 1979 to 1983 , the actual amount of foreign investment in China reached 2.683 billion US dollars, as of the end of 1995, foreign-funded enterprises total imports and exports reached 109.8 billion US dollars, up 25.3\%, accounting for the country's total import and export reached $39.1 \%$. It is worth mentioning that, in 1996, the country's foreign trade exports in the case of negative growth, foreign-funded enterprises exports still maintained more than $40 \%$-high growth rate. In the same year, China's processing trade import and export value is 146.61 billion US dollars, of which foreign-owned enterprises processing trade value is 94.6 billion US dollars, accounting for 65\% of China's processing trade. From these data, the foreign-invested enterprises in China have made an important contribution to the development of China's industrial economy.

\section{Foreign Investment Strategy to Adapt to Industrial Upgrading}

In 2001, China's accession to the WTO, to be a member of the World Trade Organization, has a significant impact on China's events, as well as on foreign investment in China. Then, China's economic development went to a new level, faced with all-round expansion of the open pattern, and a large number of small and medium manufacturing enterprises began to actively invest in the global market competition. At the same time, a large number of foreign capitals were also competing into the Chinese market with the Chinese local manufacturing enterprises to start fierce competition. Obviously, compared with the foreign investment enterprises which prior to enjoy the preferential policies such as "super national treatment", China's emerging manufacturing enterprises were obviously at a competitive disadvantageous position. After China's entry to WTO, joined the world economic system and participated in the competition against global economy, a large number of small and medium-sized manufacturing enterprises were shocked and were eliminated, but for some enterprises, it gave them opportunities to obtain more abundant resources to rise rapidly in the market. In order to adapt to the newly globalized market economic environment, and to create favorable conditions for the rise of China's manufacturing enterprises, foreign-funded enterprises have entered the stage of "national treatment" from "super-national treatment". Foreign-funded enterprises in China were no longer enjoying land acquisition, employment, tax and other forms of preferential treatment.

During the period from 2002 to 2008, China has revised the Catalog of Guidance for Foreign Investment Industries, with the aim of further strengthening the guidance on the flow of foreign investment. In 2007, the "Enterprise Income Tax Law" was adopted by foreign enterprises on the same platform as domestic enterprises. At the same time, the National Development and Reform Commis- 
sion formulated the "Eleventh Five-Year Plan for Utilizing Foreign Capital" to clarify the strategic transformation of China's future use of foreign capital policy. It can be seen that since the beginning of the 21 st century, the guiding and operability of our policies in the use of foreign capital have been gradually strengthened. The attitude towards foreign investment has also shifted from the beginning to the introduction of rational introduction, from the mere introduction of capital to industry guidance and technology introduction, so to adapt to the needs of China's economic development [4].

China is an industrial power. After 30-years reform and opening up, China's industrial development has made remarkable progress above that from the beginning of its establishment. By 2008, China's industrial added value accounted for $41 \%$ of GDP, Industrial added value reached 12999.11 billion yuan, enabling "Made in China" world-renowned. China's accession to the WTO and into the global industrial chain allowed Chinese industrial enterprises to compete for international market opportunities though with challenges. Although Chinese industry developed rapidly, but the level of technology was low, energy consumption was high, and independent innovation capacity was still weak. Those drawbacks made it at the lower part in global industrial chain [5]. Therefore, China's industrial structure needs adjustments to adapt to globalization in the context of market competition. And the full implementation of national treatment of foreign investment should not only meet foreign policy standardization requirements, but also make use of foreign investment strategy. China's industrial development strategy should be consistent internally, so to more effectively attract and utilize foreign investment. Industrial utilization of foreign capital strategy can support and promote the implementation of the strategic industrial structure, thus to upgrade the industrial structure adjustment in China, the label of "made in China" will be more notable.

\section{Foreign Manufacturing Industry for the Rise of China's Manufacturing Enterprises to Give Way}

At the beginning of the founding, China attached importance to the introduction of foreign investment to promote the development of China's economy, during this period; foreign manufacturing enterprises in China have achieved very prominent development results. As early as the 80 s of last century, US sports brand NIKE came to China, whose high-end brand image and the price helped it occupy the sports market in China. These foreign brands' prices were much higher than their manufacturing costs, but were still sought after by consumers, while China's domestic sports brand were often only a back seat at a lower price.

The outbreak of the financial crisis in 2008 exposed the problems of economic problems in various countries around the world, foreign direct investment in China once again was declining in the financial crisis, since then there has been a rising trend, but the "World Investment Report 2012" has shown a new sign of decline. According to the published World Investment Report 2012, foreign di- 
rect investment in China fell by $2 \%$ from January to May 2012 over the same period last year. At the same time, foreign investment in Southeast Asia was rapidly increasing, showing signs of leaving China. A large wave of foreign manufacturing enterprises set off a wave of divestment of China. On July 18, 2012, the German well-known sports brand Adidas told the media that their factory in Suzhou, the only one affiliated factories in China, would be closed in October this year because of "for the re-integration of global resources strategy considerations." In March 2012, the production of "Miken" carbon fiber baseball and safety equipment "First Alert" was withdrawn from Guangzhou Panyu to the United States. And Nike, as early in 2009, closed the Taicang factory in China (Nike's only footwear factory in China) and dismissed 1400 workers. In the same year, the number of the establishment of foreign investment enterprises newly approved came to 24,925 , reduced by $10.06 \%$.

The world economy is experiencing the "fourth industrial revolution". Financial crisis made the United States, Japan, Germany and other industrial power, and even the British, France and other traditional industrial power to rethink the manufacturing sector in the national economy in the strategic role, and to set up a more positive policy situation to promote advanced manufacturing development [6]. In October 2010, President Obama signed the "2010 US Manufacturing Promotion Act", these policy bills were designed to make the US manufacturing industry back to ease the problems caused by the US manufacturing industry hollow; in 2013, the German government set "German industrial strategic plan implementation suggestion 4.0". The EU proposed the "World Factory Plan" to help achieve the 2010 "European 2020" strategic objectives; in March 2015, Chinese government considered adopting "Made in China 2025". For now in a critical period, intentions of accelerating the transformation and upgrading of China's manufacturing industry will inevitably be affected by these policies. Foreign-funded enterprises are faced with the problem of how to develop sustainably.

At the same time, late-developing economies such as India, Vietnam, Bangladesh and other factors have cost advantage to speed up the transfer of low-end industries. Take the average wage of workers as an example, the current Vietnam is about 1000 yuan per month, India is about 600 yuan, and Cambodia is less than 900 yuan, while the eastern coast of China has reached 3000 yuan. Moreover, the late-developing economies also adopted preferential policies to promote the development of their manufacturing industry, such as India introduced India's first national manufacturing policy in 2011, speeding up industrial infrastructure construction, increasing efforts to improve the business environment and the establishment of "national investment and Manufacturing area "of large-scale integrated industrial towns, the development of these measures to strengthen the Indian manufacturing industry in the global competitiveness. The production capacity of the late-developing economies has been continuously enhanced in recent years, and "homogeneous competition" has been formed with "Made in China". Although the late-developing economies in industry and 
skilled workers and other aspects are still inferior to China, these countries solved the shortage of spare parts and other supporting issues. Since 2012, the number of semi-finished or product accessories has been increasing in the purchases of goods purchased by Yiwu in developing countries. They purchased semi-finished products or product parts shipped back to the country, and then sold a simple processing which can save a lot of cost. Moreover, foreign manufacturing moved along a batch of contract follow transfer that can predict the future in 5 to 10 years, the country's industrial collaboration ability and supporting facilities within the industry will gradually perfect, and its ability to undertake low-end industries transfer will be stronger [7].

In addition to the impact of the above mentioned external forces, the wave of foreign capital divestment behind China's industrial structure is accelerating the transformation and upgrading, the Chinese manufacturing is also reflected in the transformation and upgrading of the internal role. Manufacturing is not only a pillar industry of our national economy, but also a major part of China's economic growth. China's manufacturing industry, after long-term development, built an independent and sound manufacturing system, known as the "world factory." In 2013, China's manufacturing output accounted for $20.8 \%$ of the world's total, for four consecutive years to maintain the world's first, becoming the world's largest manufacturing power. However, behind these proud figures, there are problems existing in the development of China's manufacturing industry.

At present, the traditional manufacturing high investment, high consumption, high pollution and low efficiency of the extensive production has caused a serious shortage of energy; the ecological environment is deteriorating sharply [8]. Manufacturing in the production process needs to consume a lot of energy, and such energy is often non-renewable. Unreasonable energy use will lead to energy waste and environmental degradation, and the rational use of energy and improve energy efficiency is China's energy-saving emission reduction and sustainable development of the most realistic and effective way. Science and technology play a vital role in the transition from extensive manufacturing to intensive new manufacturing. Only making full use of modern science and technology, relying on scientific and technological innovation and technological progress, increasing human capital and R \& D investment can we improve efficien$c y$, reduce energy consumption and reduce environmental pollution during the transformation and upgrading of traditional manufacturing and development of high-tech industries, thus, to promote the real realization of China's manufacturing industry from big to strong.

It has been mentioned that China's manufacturing industry is still in the low end of the world's industrial chain, the relative backwardness of the manufacturing technology process, the excess capacity and the lack of independent innovation gives China's manufacturing industry a large but not strong situation, lacking of ability to compete with the world's high-end brands. "Made in China" relies on cheap labor and a large number of consumption of resources with the 
"Lewis turning point" and the arrival of the limited resources of the depletion and gradually collapsed [9]. On May 19, 2015, the State Council issued the "Made in China 2025", the deployment of a comprehensive plan to promote the implementation of power strategy. "Made in China 2025" this general idea is to adhere to the new characteristics of China's industrialization path to promote the development of manufacturing innovation as the theme, to improve quality and efficiency as the center, to speed up a new generation of information technology and manufacturing integration as the main line, to promote intelligence manufacturing to the main direction, to meet the economic and social development and national defense construction of major technical equipment needs as the goal, to strengthen the industrial base capacity, improve the level of comprehensive integration, to improve the multi-level talent system, promote industrial transformation and upgrading, to achieve manufacturing by the "big" change the historical leap of "strong" [10]. "Made in China 2025" will be implemented by manufacturing innovation center industrial technology research base construction project; intelligent manufacturing engineering; strong industrial base engineering; green manufacturing engineering; high-end equipment innovation engineering and five projects will enter the manufacturing powerhouse.

Simply relying on cheap labor and a lot of consumption of resources to develop the manufacturing industry will gradually come to an end, replaced by the overall quality of the manufacturing sector, to significantly enhance the ability of innovation, full improvement in labor productivity (industrialization and information technology) to a new level. Obviously, in this context, relying on China's cheap human and material resources in the manufacturing chain at the top of the foreign manufacturing industry will eventually make it lose the development of manufacturing advantages in China, appearing to a large number of foreign manufacturing industries to withdraw China's wave, which is an inevitable trend of the development of manufacturing industry. In order to make the "Made in China" reputation truly world-renowned, "Made in China" should be incorporated with more "China to Create" and "China Service" components, it is necessary, with the "Made in China 2025" implementation, to achieve China's manufacturing Power of the strategic objectives.

\section{Conclusions}

Through the above content, we can realize that all stages of economic development in China to formulate the corresponding foreign policy are matched with the economic development present situation and development needs. Both at the beginning of the reform and opening to the outside of the "super national treatment" stage, or having entered the stage of "national treatment", foreign manufacturing in all stages of economic development in China has played a certain role, and for the development of China's economy has made an indelible contribution. Foreign manufacturing industry development in China, however, has had its day in the lonely gradually, it is the inevitable result of China's manufacturing industry development process and is the necessity of "Made in China" 
that becomes bigger and stronger. Therefore, in the face of a wave of foreign manufacturing divestment, enterprises should set up the correct understanding, to make the right judgment, to adapt to the inevitable developing trend of China's manufacturing industry, with "made in China 2025" leading the development direction, changing the style of the original extensive manufacturing development on the manufacturing of high quality, high level development. In this paper, the main research significance is to analyze the foreign capital withdrawal, the real reasons behind and expound the inevitability of foreign divestment occurrences, thereby lifting some concerns about China's economic development, promoting enterprises to meet "made in China 2025". Foreign manufacturing needs to rethink its position in the Chinese market and develop a new strategy to adapt to a market in which the industrial structure is upgraded.

In this paper, there are many limitations and shortcomings. While this article collected the relevant data to illustrate the different historical periods, the foreign investment policy and the adaptability of China's economic development, on the one hand, the use of limited data, however, is not a large number of detailed and summarized data. On the other hand, there was no scientific data analysis used to verify the views in this article, which made the conclusions less convincing. At the same time, the discussion of this article is based on the analysis of real events, and not from the theory; there is no reliable theoretical basis. Therefore, in future research, scientific data analysis can be adopted to verify the conclusions in this article so to enhance the scientificity. Besides, we shall start from theories to make it theoretical as well.

\section{References}

[1] Sun, Y.F. (2006) Foreign Investment, Super National Treatment and the Government Decision-Making. Journal of Economist, 7, 86-87.

[2] Li, B.L. (2001) Reflection of "Super National Treatment" to Foreign Investment in the New Period of China. Journal of Truth-Seeking, 10, 32-35.

[3] Chen, Y.J. and Yang, Z. (2012) Foreign Investment in Manufacturing and Market Power Fluctuations: Competition or Monopoly. China Industrial Economy, 10, 52 64.

[4] Yang, Z. (2014) Foreign Investment in Technical Efficiency and Resource Allocation Efficiency of Study, Based on the Empirical Analysis of China's Manufacturing Micro Data. Industrial Economic Research, 6, 60-68.

[5] Liu, J., Cheng, Z.H. and Li, L.S. (2015) China's Manufacturing Industry Development: Status, Trends and Difficulties. Journal of Yue Jiang, 4, 15-21.

[6] Yang, L. and Wu, G.Y. (2007) Multinationals Divestment in China: Dynamics, Influence and Countermeasures. Journal of Economic System Reform, 4, 31-35.

[7] Liu, G.Y. (2012) Historical Evolution and the Paradigm of China's Foreign Investment Policy Evaluation. Journal of Reform, 12, 132-137.

[8] Wang, L. and Li, H.Y. (2015) China's Manufacturing Industry into the Global Value Chain Research Path-The Embedding Position and Value Perspective. China Industrial Economy, 2, 76-88.

[9] Li, X.P., Zhou, J.S. and Wang, S.B. (2015) The Ascension of the Export of Chinese Manufacturing Complexity and Manufacturing Growth. Journal of World Econo- 
$m y, 2,31-57$.

[10] Huang, Q.H. and He, J. (2005) The Core Competence of China's Manufacturing Industry, Function Orientation and Development Strategy, and A Review of the "Made in China 2025". China Industrial Economy, 6, 5-17.

Submit or recommend next manuscript to SCIRP and we will provide best service for you:

Accepting pre-submission inquiries through Email, Facebook, LinkedIn, Twitter, etc. A wide selection of journals (inclusive of 9 subjects, more than 200 journals)

Providing 24-hour high-quality service

User-friendly online submission system

Fair and swift peer-review system

Efficient typesetting and proofreading procedure

Display of the result of downloads and visits, as well as the number of cited articles Maximum dissemination of your research work

Submit your manuscript at: http://papersubmission.scirp.org/

Or contact ajibm@scirp.org 